\title{
Ocean acidification limits temperature-induced poleward expansion of coral habitats around Japan
}

\author{
Y. Yara ${ }^{1,2}$, M. Vogt ${ }^{3}$, M. Fujii ${ }^{1}$, H. Yamano ${ }^{2}$, C. Hauri ${ }^{4}$, M. Steinacher ${ }^{5,6}$, N. Gruber ${ }^{3}$, and Y. Yamanaka ${ }^{1}$ \\ ${ }^{1}$ Faculty of Environmental Earth Science, Hokkaido University, Sapporo, Japan \\ ${ }^{2}$ Center for Environmental Biology and Ecosystem Studies, National Institute for Environmental Studies, Tsukuba, Japan \\ ${ }^{3}$ Environmental Physics Group, Institute of Biogeochemistry and Pollutant Dynamics, ETH Zurich, Zurich, Switzerland \\ ${ }^{4}$ School of Fisheries and Ocean Sciences, University of Alaska Fairbanks, Fairbanks, Alaska, USA \\ ${ }^{5}$ Climate and Environmental Physics, Physics Institute, University of Bern, Bern, Switzerland \\ ${ }^{6}$ Oeschger Centre for Climate Change Research, University of Bern, Bern, Switzerland
}

Correspondence to: Y. Yara (yara.yumiko@nies.go.jp)

Received: 27 April 2012 - Published in Biogeosciences Discuss.: 18 June 2012

Revised: 14 October 2012 - Accepted: 17 October 2012 - Published: 4 December 2012

\begin{abstract}
Using results from four coupled global carbon cycle-climate models combined with in situ observations, we estimate the effects of future global warming and ocean acidification on potential habitats for tropical/subtropical and temperate coral communities in the seas around Japan. The suitability of coral habitats is classified on the basis of the currently observed regional ranges for temperature and saturation states with regard to aragonite $\left(\Omega_{\mathrm{arag}}\right)$. We find that, under the "business as usual" SRES A2 scenario, coral habitats are projected to expand northward by several hundred kilometers by the end of this century. At the same time, coral habitats are projected to become sandwiched between regions where the frequency of coral bleaching will increase, and regions where $\Omega_{\text {arag }}$ will become too low to support sufficiently high calcification rates. As a result, the habitat suitable for tropical/subtropical corals around Japan may be reduced by half by the 2020s to 2030s, and is projected to disappear by the 2030s to 2040s. The habitat suitable for the temperate coral communities is also projected to decrease, although at a less pronounced rate, due to the higher tolerance

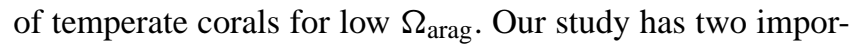
tant caveats: first, it does not consider the potential adaptation of the coral communities, which would permit them to colonize habitats that are outside their current range. Second, it also does not consider whether or not coral communities can migrate quickly enough to actually occupy newly emerging habitats. As such, our results serve as a baseline for the assessment of the future evolution of coral habitats, but the
\end{abstract}

consideration of important biological and ecological factors and feedbacks will be required to make more accurate projections.

\section{Introduction}

Today's distribution of hermatypic (reef-building) corals is confined to a relatively narrow range of sea surface temperatures (SST) and of the saturation state of the mineral carbonate aragonite $\left(\Omega_{\text {arag }}\right)$ (Hoegh-Guldberg, 2005). Tropical corals usually do not tolerate SSTs below $18^{\circ} \mathrm{C}$ (e.g., Kleypas et al., 1999a) and are subject to bleaching if SST during the hottest months exceeds the climatological values by more than $2{ }^{\circ} \mathrm{C}$ for at least one month (Hoegh-Guldberg et al., 2007; Frieler et al., 2012). As a result, hermatypic corals are largely confined to the tropical/subtropical latitudes of the world's ocean. Due to their dependence on the formation of an aragonite skeleton, corals are also sensitive to the carbonate ion concentration, $\left[\mathrm{CO}_{3}^{2-}\right]$, and to $\Omega_{\mathrm{arag}}$. There is growing evidence that low $\mathrm{pH}$ and $\Omega_{\text {arag }}$ impact the coral's physiological processes negatively, especially their calcification rates (e.g., Gattuso et al., 1998; Kleypas et al., 1999a; Langdon et al., 2000, 2003), their overall productivity (Anthony et al., 2008) and also their reproduction (Morita et al., 2009) and recruitment success (Albright et al., 2010). Experiments have also shown that exposure to low $\mathrm{pH}$ and $\Omega_{\text {arag }}$ makes corals more prone to bleaching (Anthony et al., 2011). 
Although hermatypic corals do not have a common threshold for $\Omega_{\text {arag }}$ and $\left[\mathrm{CO}_{3}^{2-}\right]$ below which their physiological health is compromised, the current distribution of coral reefs in the Pacific Ocean suggests a strong sensitivity to ocean $\mathrm{pH}$ and $\Omega_{\text {arag }}$ : most coral reefs exist in waters with an $\Omega_{\mathrm{arag}}$ of more than 3 (Kleypas et al., 1999b; Guinotte et al., 2003), although few exist at lower values (Manzello, 2010; Cohen and Holcomb, 2009). Based on these $\Omega_{\text {arag }}$ thresholds, Guinotte et al. (2003) classified hermatypic coral habitats with an $\Omega_{\text {arag }}<3$ as "extremely marginal", habitats with $3 \leq \Omega_{\text {arag }}<3.5$ as "marginal", and habitats with an $\Omega_{\text {arag }} \geq 3.5$ as "adequate to optimal". With regard to temperature, they defined the range suitable for coral growth where SST $>18.4^{\circ} \mathrm{C}$ in the coldest months, and where it does not exceed $31.1^{\circ} \mathrm{C}$ during the hottest months of each year.

The human-induced increase in atmospheric $\mathrm{CO}_{2}$ changes the distribution of suitable habitats for warm-water corals in at least two ways: first, rising sea surface temperatures in response to global warming will permit coral habitats to expand poleward (Precht and Aronson, 2004; Yamano et al., 2011), while at the same time possibly limiting their habitat in the tropics due to excessive bleaching (Guinotte et al., 2003; Meissner et al., 2012), despite their possible potential of thermal adaptation (Frieler et al., 2012). Second, lowered $\Omega_{\text {arag }}$ due to the uptake of anthropogenic $\mathrm{CO}_{2}$ from the atmosphere will affect the growth and fitness of corals everywhere, but particularly at higher latitudes, where the saturation state will reach critically low levels first (Kleypas et al., 1999b; Orr et al., 2005; Steinacher et al., 2009). The rise in atmospheric $\mathrm{CO}_{2}$ of more than $30 \%$ since pre-industrial times has increased global average SST by at least $0.5^{\circ} \mathrm{C}$ (Trenberth et al., 2007) and has lowered surface ocean $\mathrm{pH}$ by about 0.1 units and ocean $\Omega_{\text {arag }}$ by about 0.3 units (Feely et al., 2004). If $\mathrm{CO}_{2}$ continues to rise unabatedly, much larger changes are in store, i.e., increases in SST of several degrees celsius and drops in $\mathrm{pH}$ of up to nearly one unit and even more for $\Omega_{\text {arag }}$ (e.g., Feely et al., 2009).

Kleypas et al. (1999b) were the first to systematically investigate the impact of future ocean acidification on warmwater coral habitats on a global scale. They highlighted that, in a "business as usual" scenario with atmospheric $\mathrm{CO}_{2}$ increasing to double its pre-industrial value in 2065 , the drop in $\Omega_{\text {arag }}$ moves most of the current habitats for warm water corals outside the suitable range. Guinotte et al. (2003) extended this analysis by including also the effect of rising temperatures. They pointed out that the warming of the tropical Pacific puts much of the western tropical Pacific above the bleaching threshold of $31.1^{\circ} \mathrm{C}$, further stressing coral communities. More recently, Meissner et al. (2012) revisited these findings by using a model of intermediate complexity and investigating a new set of emission scenarios. They confirm many of these previous findings, also emphasizing the combined stress by warming and decreased saturation states. They project that most of the tropical/subtropical coral reefs will experience severe bleaching events by the 2030s-2050s, but that the impact of the changes in $\Omega_{\text {arag }}$ will tend to exceed the impact of the changes in SST. Most recently, Frieler et al. (2012) looked at the impact of different emission scenarios and reported that, even under the most optimistic IPCC emission scenario RCP3-PD, roughly one-third of the current coral reefs will be subject to severe bleaching by the end of this century. All these studies focus on tropical corals, and do not investigate changes in future temperate or deep water coral habitats.

In contrast to the reduction of the tropical habitats due to increased bleaching, the possible poleward extension of suitable habitats due to the warming of higher-latitude regions to temperatures well above the lower temperature threshold for coral growth has received less attention (Precht and Aronson, 2004; Greenstein and Pandofli, 2008), or is not considered at all (Frieler et al., 2012). Recently, Yamano et al. (2011) demonstrated on the basis of long-term coral observations that such a northward expansion has already occurred along the coastlines of Japan. Yara et al. (2009, 2011) investigated the potential future development of this northward expansion along the coasts of Japan, suggesting that this trend might continue for several decades. However, they took into account only the change in temperature, but not changes in the saturation state.

Here, we build on this prior work and investigate the future development of potential habitats for coral communities in the seas close to Japan. In addition to warm water (tropical/subtropical) coral communities that contribute to reef building, we also focus on the habitat distribution of temperate coral communities, which have not been discussed extensively in the literature. Japan offers a unique opportunity to study the impacts of ocean warming (bleaching and poleward range expansion) and acidification, as it covers a wide latitudinal range, stretching from subtropical to temperate areas (Fig. 1). Furthermore, the coral distribution around the Japanese islands has been well described, permitting researchers to assess future changes against a well-established current state. In fact, some of the climate change-induced consequences for corals have already been observed in Japan. Severe bleaching events were observed in the summers of 1998 and 2007 in the southern part of Japan as a result of SSTs exceeding $30^{\circ} \mathrm{C}$ for at least one month (e.g., Kayanne et al., 1999). In addition, based on an in situ SST time series and an inventory of corals around Japan that dates back to the 1930s, Yamano et al. (2011) described a temperatureinduced poleward range expansion of tropical coral species to temperate areas at speeds of up to $14 \mathrm{~km} \mathrm{yr}^{-1}$.

The northern limit of coral reefs dominated by coral communities typically found in tropical/subtropical regions is currently situated at Tanegashima Island $\left(30.7^{\circ} \mathrm{N}, 131.0^{\circ} \mathrm{E}\right)$ and Mageshima Island $\left(30.4^{\circ} \mathrm{N}, 130.5^{\circ} \mathrm{E}\right)$, of Kagoshima Prefecture (Hori, 1980; Nakai, 1990; Kan et al., 2005; Ikeda et al., 2006), where the observed SST during the coldest months is $18^{\circ} \mathrm{C}$ and annual mean surface $\Omega_{\text {arag value is 3.4. }}$. These limits are generally consistent with those established 


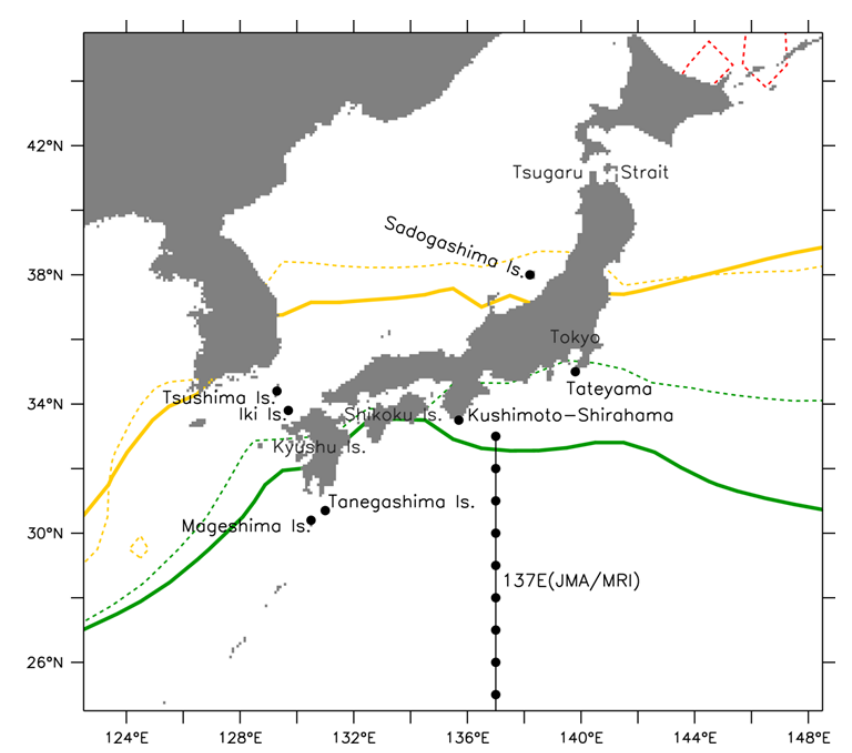

Fig. 1. Study site locations. At present, Sadogashima Island $\left(138.2^{\circ} \mathrm{E}, 38.0^{\circ} \mathrm{N}\right)$ marks the northern limit of the temperate coral occurrence. Kushimoto-Shirahama $\left(135.7^{\circ} \mathrm{E}, 33.5^{\circ} \mathrm{N}\right)$ and Tateyama $\left(139.8^{\circ} \mathrm{E}, 35.0^{\circ} \mathrm{N}\right)$ are located in the current transition area of the tropical/subtropical coral community and the temperate coral community. The JMA/MRI cruise was a $137^{\circ} \mathrm{E}$ transect used to validate the projected SST and $\Omega_{\mathrm{arag}}$. Isothermal lines of SST $=18^{\circ} \mathrm{C}$ (solid green line) and $10^{\circ} \mathrm{C}$ (solid yellow line) and isolines of $\Omega_{\text {arag }}=3.0$ (dotted green line), 2.3 (dotted yellow line) and 1.0 (red dotted line) during the coldest months are also presented.

for the whole Pacific (e.g., Kleypas et al., 1999a, 2006), although some coral reefs exist in waters with $\Omega_{\text {arag }}<3$ (e.g., Manzello, 2010; Cohen and Holcomb, 2009).

Corals are also frequently found in the temperate areas of Japan. They normally do not contribute to reef-building, though the world's most northerly coral reefs are found at Iki and Tsushima islands $\left(34.1^{\circ} \mathrm{N}, 129.5^{\circ} \mathrm{E}\right.$ ) (Yamano et al., 2012). The northernmost coral species (Oulastrea crispata) around Japan is currently found at Sadogashima Island $\left(38.0^{\circ} \mathrm{N}, 138.2^{\circ} \mathrm{E}\right.$ ), of Niigata Prefecture (Honma and Kitami, 1978), where SST gets as low as $10^{\circ} \mathrm{C}$ during the coldest months. Also, the lowest values of $\Omega_{\text {arag }}$ at these locations reach levels of around $\Omega_{\text {arag }}=2.3$, with values calculated from observed data of SST, sea surface salinity (SSS), and $\mathrm{pH}$ from Niigata Prefectural Fisheries and Marine Research Institute (2007, 2008, 2009 and 2010) and total alkalinity from Lee et al. (2006). Thus, Japan's two coral communities, i.e., the tropical/subtropical and temperate corals, have very different tolerance ranges for SST and $\Omega_{\text {arag }}$, likely leading to different responses to future climate change.

In order to quantify these different responses, we examine the effects of warming (bleaching and poleward range expansion) and ocean acidification until the end of this century for a "business as usual" $\mathrm{CO}_{2}$ emission scenario (SRES A2).
We use simulations from four fully coupled global threedimensional (3-D) atmospheric-ocean climate models that include complete carbon cycle modules (Steinacher et al., 2009,2010 ). We add the changes projected from these models to present-day climatologies in order to obtain a best estimate of the future trajectories of SST and $\Omega_{\text {arag }}$ in the nearsurface ocean. We compare the speed of poleward range expansion of coral species to the speed of change in the aragonite saturation state $\Omega_{\mathrm{arag}}$, and provide an updated projection of coral habitat marginality for the 21 st century around the coast of Japan for both tropical/subtropical and temperate coral habitats. Though our analysis is limited to the definition of habitat suitability on the basis of simple indices (SST and $\Omega_{\text {arag }}$ ), it serves as a baseline to project and understand the future status of corals under the high $\mathrm{CO}_{2}$ emission scenario (SRES A2). Our study does not explicitly consider the possibility of adaptation, but we discuss the importance of this process and the temporal/spatial variability in the responses of corals to climate change (e.g., Pandolfi et al., 2011).

\section{Methods}

\subsection{Climatological data and future projections}

To project the effects of global warming and ocean acidification on coral habits for this century, we combine results from climate models for the coming decades with present-day climatological observations.

Given the lack of a surface ocean monthly climatology of $\Omega_{\mathrm{arag}}$, we computed monthly $\Omega_{\mathrm{arag}}$ values on the basis of monthly fields of dissolved inorganic carbon (DIC), alkalinity (ALK), sea surface temperature (SST), sea surface salinity (SSS), phosphate $\left(\mathrm{PO}_{4}\right)$ and silicic acid $\left(\mathrm{Si}(\mathrm{OH})_{4}\right)$. The latter four variables were taken from the World Ocean Atlas, version 2005 (WOA05). We computed surface ALK from monthly mean SST and SSS using the method detailed in Lee et al. (2006). We then calculated monthly mean DIC from monthly mean ALK and monthly mean sea surface $p \mathrm{CO}_{2}$ from Takahashi et al. (2009) using the OCMIP (Ocean Carbon-Cycle Model Intercomparison Project) carbonate chemistry routines (http://www.ipsl.jussieu.fr/OCMIP/ phase3/simulations/NOCES/HOWTO-NOCES-3.html), and SST, SSS, and the nutrients $\mathrm{PO}_{4}$ and $\mathrm{Si}(\mathrm{OH})_{4}$ from WOA05. All these monthly fields were then used to compute the monthly climatology of $\Omega_{\text {arag }}$ using the same OCMIP routines. The monthly DIC and $\Omega_{\text {arag }}$ fields correspond to a climatological year 2000, owing to the use of the surface $p \mathrm{CO}_{2}$ fields of Takahashi et al. (2009), which were adjusted to this reference year. All data were interpolated onto a $1^{\circ} \times 1^{\circ}$ grid for the western North Pacific (area bounded by $24^{\circ}-48^{\circ} \mathrm{N}$, $\left.118^{\circ}-157^{\circ} \mathrm{E}\right)$.

To project the seasonal climatological distributions forward in time, we used annual mean SST and $\Omega_{\text {arag }}$ from four fully coupled global 3-D atmospheric-ocean climate 
models for 1980-2099. The models are the IPSL-CM4LOOP model (IPSL; Friedlingstein et al., 2006), the Earth system model employed at the Max Planck Institute for Mathematics (MPIM; Marsland et al., 2003; Maier-Reimer et al., 2005; Roeckner et al., 2006), the NCAR CSM1.4carbon climate model (Fung et al., 2005; Doney et al., 2006), and the NCAR CCSM3 Biogeochemical Elemental Cycling Model (Moore et al., 2004). All models contain a carbon cycle module for both terrestrial and oceanic compounds, and three of the four models contributed to the IPCC Fourth Assessment Report (IPCC, 2007; Meehl et al., 2007; Solomon et al., 2007). The horizontal resolution of the models is $2^{\circ} \times 2^{\circ}, 1.5^{\circ} \times 1.5^{\circ}, 3.6^{\circ} \times 0.8^{\circ}-1.8^{\circ}$ and $3.6^{\circ} \times 1^{\circ}-2^{\circ}$ for IPSL, MPIM, CSM1.4, and CCSM3, respectively. The experimental setup for the future climate runs is described in Steinacher et al. (2010). Briefly, after a spin-up period of more than $1000 \mathrm{yr}$ under pre-industrial conditions, the models were forced with prescribed $\mathrm{CO}_{2}$ emissions from reconstructions over the 19th and 20th centuries and following the SRES-A2 emission scenario for 2000-2099 (IPCC, 2000). Carbonate ion concentration and the carbonate saturation state were calculated offline from modeled quantities using the standard OCMIP carbonate chemistry routines (see Steinacher et al., 2009 for details). All model data were interpolated on a regular $1^{\circ} \times 1^{\circ}$ grid to match the spatial resolution of the observational data described in the preceding section. We use the changes in SST and $\Omega_{\text {arag }}$ relative to the present day from the climate models, and add these anomalies to the present-day monthly climatological distributions to construct a more accurate description of the future projections. This method has been applied frequently in order to remove biases in the model mean-states (e.g., Orr et al., 2005; Yara et al., 2009, 2011).

To produce the final monthly fields for SST and $\Omega_{\text {arag }}$ for the 21 st century, we added the modeled annual mean SST

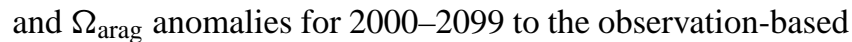
monthly climatologies. We thereby assumed cyclostationary seasonal cycles for SST and $\Omega_{\text {arag }}$ during the 21 st century, which is generally supported by results from climate models (Steinacher et al., 2009), although there is a tendency for the seasonal cycle of $\Omega_{\text {arag }}$ to increase with time, due to the decreasing buffer capacity of the ocean (Rodgers et al., 2008). The modeled anomalies were computed subtracting the modeled climatological 20 -yr mean SST and $\Omega_{\text {arag }}$ over the 1980-1999 period from the modeled time series of SST and $\Omega_{\text {arag. }}$. From the seasonal envelope, we derived SST during the hottest/coldest months of each year, and the lowest monthly $\Omega_{\text {arag }}$ for each year. Finally, we calculated the decadal means of the bias-corrected SST of the hottest/coldest and annual lowest $\Omega_{\text {arag }}$ for each decade between 2000 and 2099.

One limitation in our approach is the use of models with a relatively coarse spatial resolution, which are unable to represent the fine-scale physical and chemical changes in near coastal areas associated with global warming and ocean acidification (e.g., Gruber et al., 2012). Although we minimize this effect through our combining the model anomalies with present-day climatologies, our habitat characterization should not be viewed as a correct characterization of the changes in the near-shore $(<50 \mathrm{~km})$, but rather as reflecting the larger-scale $(\sim 100 \mathrm{~km})$ changes in the area. Thus, when computing the suitable coral habitats, we do this at the $1^{\circ} \times 1^{\circ}$ resolution of our grid, using also the coastline at this resolution to delineate land from ocean.

\subsection{Suitability of coral habitats}

We determine the potential future habitats for corals in terms of regions with a given annual range in SST and $\Omega_{\mathrm{arag}}$. For the tropical/subtropical (reef-building) coral community, we use the $18^{\circ} \mathrm{C}$ isotherm during the coldest months of each year as the northern limit, and the $30^{\circ} \mathrm{C}$ isotherm during the hottest months of each year as a southern limit (Kayanne et al., 1999). For the temperate coral community, the northern limit was set to the $10^{\circ} \mathrm{C}$ isoline during the coldest month of each year. These thresholds are the same as those used by Yara et al. $(2009,2011)$ and reflect also today's distributional limits of coral reefs and corals in Japan, respectively.

Following Kleypas et al. (1999b) and Guinotte et al. (2003), we adopted the isoline of $\Omega_{\mathrm{arag}}=3$ at the annual lowest value of each year as the northern limit of the tropical/subtropical coral community. For the temperate coral community, the isoline of $\Omega_{\text {arag }}=2.3$ at the annual lowest value of each year was chosen as the northern limit. This latter threshold was chosen because it corresponds to the annual minimum at the current northern limit of coral occurrence at Sadogashima Island (Niigata Prefectural Fisheries and Marine Research Institute, 2007, 2008, 2009, 2010). The isoline of $\Omega_{\mathrm{arag}}=1$, below which aragonite dissolves, at the annual lowest value for each year, was also examined as a reference.

We calculated the percentage of coastal waters within a certain range of SST and $\Omega_{\text {arag }}$ as an indicator of habitat suitability for the two different coral communities (see Table 1). Tropical/subtropical coral habitats are defined as "suitable" when $18^{\circ} \mathrm{C} \leq \mathrm{SST}<30^{\circ} \mathrm{C}$ and $\Omega_{\mathrm{arag}} \geq 3.5$, "marginal" when $3 \leq \Omega_{\text {arag }}<3.5$, and "unsuitable" when SST $\geq 30^{\circ} \mathrm{C}$ or $\Omega_{\text {arag }}<3$. The habitats for temperate coral communities were defined as "suitable" if $10^{\circ} \mathrm{C} \leq \mathrm{SST}<18^{\circ} \mathrm{C}$ and $\Omega_{\text {arag }} \geq 2.3$, "marginal" when $1 \leq \Omega_{\text {arag }}<2.3$, and "unsuitable" if $\Omega_{\text {arag }}<1$. No observational evidence for a SST threshold between marginal and unsuitable regimes has been reported for the northernmost boundary of temperate coral occurrence, and the threshold will not be discussed in this study. These thresholds defining the suitability of the coral habitats are an approximation only, due to the scarcity of experimental evidence, and should be used as guidelines to document the changes in SST and $\Omega_{\mathrm{arag}}$, rather than as absolute thresholds. 
Table 1. Habitat characterization for the tropical/subtropical and the temperate coral communities.

\begin{tabular}{|c|c|c|c|c|}
\hline & \multicolumn{2}{|c|}{ Tropical/subtropical corals } & \multicolumn{2}{|c|}{ Temperate corals } \\
\hline & SST & $\Omega_{\text {arag }}$ & SST & $\Omega_{\text {arag }}$ \\
\hline Suitable & $18^{\circ} \mathrm{C} \leq \mathrm{SST}<30^{\circ} \mathrm{C}^{\mathrm{a}}$ & $\Omega_{\operatorname{arag}} \geq 3.5^{\mathrm{c}}$ & $10^{\circ} \mathrm{C} \leq \mathrm{SST}<18^{\circ} \mathrm{C}^{\mathrm{a}, \mathrm{d}}$ & $\Omega_{\text {arag }} \geq 2.3^{\mathrm{a}}$ \\
\hline Marginal & Undefined & $3 \leq \Omega_{\text {arag }}<3.5^{\mathrm{c}}$ & Undefined & $1 \leq \Omega_{\text {arag }}<2.3^{\mathrm{a}}$ \\
\hline Unsuitable & $\mathrm{SST} \geq 30^{\circ} \mathrm{C}^{\mathrm{b}}$ & $\Omega_{\text {arag }}<3^{\mathrm{c}}$ & Undefined & $\Omega_{\text {arag }}<1^{\mathrm{a}}$ \\
\hline
\end{tabular}

Sources: ${ }^{\text {a }}$ Kleypas et al. (1999b); ${ }^{\mathrm{b}}$ Kayanne et al. (1999); ${ }^{\mathrm{c}}$ Guinotte et al. (2003); ${ }^{\mathrm{d}}$ this study.

An important caveat in our habitat characterization is that we assume that the present-day distribution of the different coral communities reflects their realized environmental niche, i.e., that they cannot successfully establish themselves outside their current SST and $\Omega_{\text {arag }}$ ranges. We furthermore assume that these communities will not be able to adapt to the changes, and hence need to change their habitats relative to today's conditions. We will discuss the implications of these assumptions in Sect. 3.4.

\section{Results and discussion}

\subsection{Data evaluation}

Given the derived nature of the computed monthly climatological $\Omega_{\text {arag }}$ distribution around Japan, it is critical to evaluate this product with in situ observations. Two datasets were used to this end: first, winter cruise data from the Japanese Meteorological Agency (JMA)/Meteorological Research Institute (MRI) for 1983-1999 (Midorikawa et al., 2010; Ishii et al., 2011) along the transect at $24^{\circ}-33^{\circ} \mathrm{N}, 137^{\circ} \mathrm{E}$ (Fig. 1) and second, monthly station data for Sadogashima Island $\left(38.0^{\circ} \mathrm{N}, 138.2^{\circ} \mathrm{E}\right)$ for $2005-2009$. The latter were measured at a depth of $2.5 \mathrm{~m}$ at 04:00 p.m. local time each day (Niigata Prefectural Fisheries and Marine Research Institute, 2007, 2008, 2009, 2010; Fig. 1).

The WOA05/Takahashi-based climatological SST during the coldest months and the annual lowest $\Omega_{\text {arag }}$ for each year correlate well with those measured in the JMA/MRI winter cruise data (Midorikawa et al., 2010; Ishii et al., 2011; Fig. 2a, b; $R^{2}=0.95$ and 0.96 for SST and $\Omega_{\text {arag }}$, respectively). However, our WOA05/Takahashi-based SST and $\Omega_{\text {arag }}$ are biased low, on average, by $0.5^{\circ} \mathrm{C}$ and 0.16 units. The WOA05/Takahashi-based SST and $\Omega_{\text {arag }}$ correlate also well with the in situ data at Sadogashima Island $\left(R^{2}=0.98\right.$ for SST and 0.79 for $\Omega_{\text {arag }}$, respectively; Fig. 2c, d). Almost no bias was observed for the WOA05-based SST with respect to these in situ observations (slopes of 1.00 and no offset), but $\Omega_{\text {arag }}$ is systematically biased low by about 0.9 units. This bias is largely due to a slope that is only half as large as the one of the $1: 1$ line, leading to high underestimations of $\Omega_{\text {arag }}$ at high $\Omega_{\text {arag }}$, but low underestimations of $\Omega_{\text {arag }}$ at low $\Omega_{\text {arag. }}$.
Differences in $\Omega_{\text {arag }}$ may be due to the different temporal and spatial resolutions of the WOA05/Takahashi-based data with respect to in situ observations. Recognizing the partially substantial discrepancies between the WOA05/Takahashibased data and the in situ observations, we nevertheless use the WOA05/Takahashi-based data for our subsequent analyses. This is mostly because they permit us to cover all areas, while the in situ data are available from only a highly limited number of places. The uncertainty arising from the modeldata misfits will be discussed in more detail in Sect. 3.4.

\subsection{Projected shifts in tropical/subtropical and temperate coral habitats}

Over the course of the 21 st century, the average isolines of SST $=18^{\circ} \mathrm{C}$ and $10^{\circ} \mathrm{C}$ during the coldest months, i.e., the isolines that define the northernmost boundaries of the tropical/subtropical and temperate coral communities, respectively, are projected to shift consistently poleward (Fig. 3). As the coral habitats move northward, the corals are increasingly immersed in waters with a low $\Omega_{\text {arag. The isolines of }}$ $\Omega_{\text {arag }}=3$ and 2.3 , which define the northernmost boundaries of the two coral communities, are progressively moving southward, due to ocean acidification. We investigate these shifts in the suitable habitats in more detail in the next sections, and separately for both the tropical/subtropical and the temperate coral communities. Since the potential of corals to adapt to changes in their biogeochemical environment remains a topic of active scientific research, and cannot be taken into account in a quantitative manner in current model simulations, we investigate changes in the current habitats of tropical/subtropical and temperate corals as a worst case scenario, and disregard the possibility of adaptation. However, we will discuss the implication of this assumption in detail in the sections below.

\subsubsection{Tropical/subtropical coral communities}

In the 2000s, the calculated northern limit of the tropical/subtropical coral community is located in southwest Japan (Fig. 3), which agrees with previous observations (e.g., Veron, 1995; Kleypas et al., 1999a; Buddemeier et al., 2004). All the habitats to the south of this line are bathed in waters with $\Omega_{\text {arag }} \geq 3$; i.e., they are all suitable for 
(a) JMA/MRI $137^{\circ} \mathrm{E}$ line

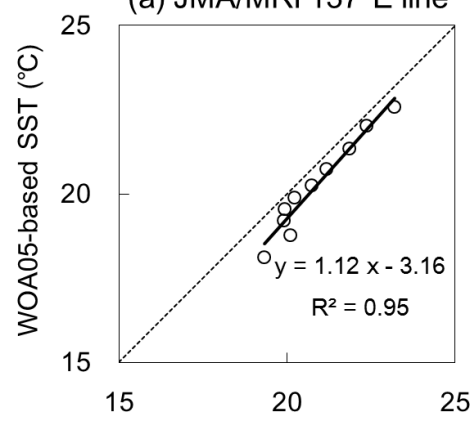

(c) Sadogashima Island

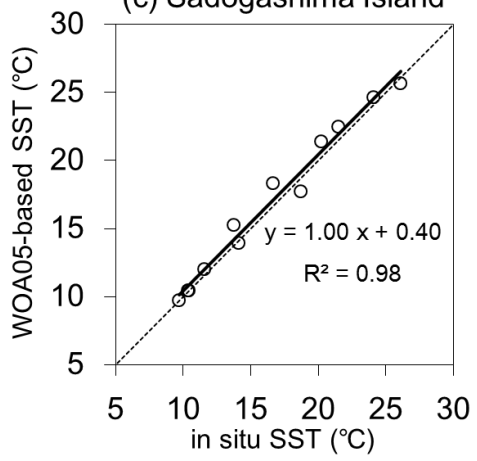

(b) JMA/MRI $137^{\circ} \mathrm{E}$ line

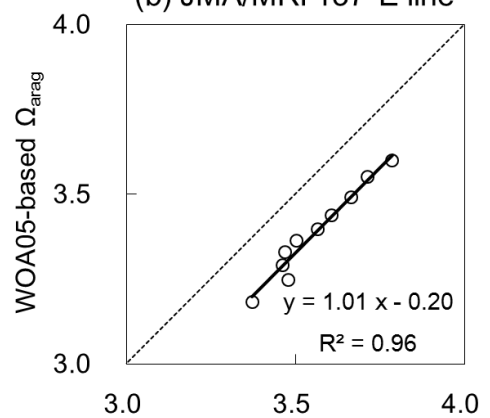

(d) Sadogashima Island

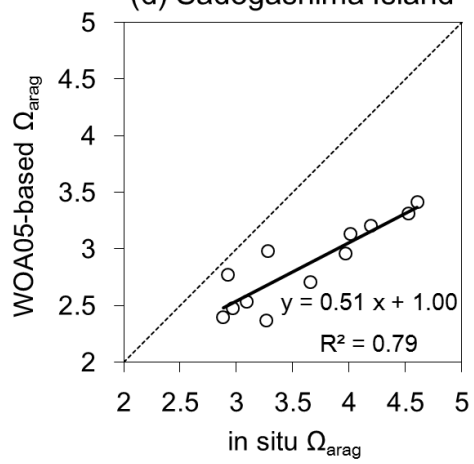

Fig. 2. WOA05-based monthly climatology vs. in situ diagram of (a) monthly SST and (b) monthly $\Omega_{\text {arag }}$ on the JMA/MRI transect from $24^{\circ} \mathrm{N} / 137^{\circ} \mathrm{E}$ to $33^{\circ} \mathrm{N} / 137^{\circ} \mathrm{E}$ in winter (January and February), and (c) monthly SST and (d) monthly $\Omega_{\text {arag in Sadogashima Is- }}$ land $\left(138.2^{\circ} \mathrm{E}, 38.0^{\circ} \mathrm{N}\right)$ for 2005-2009, respectively. In situ data are based on Midorikawa et al. (2010) and Ishii et al. (2011) for (a) and (b), and Niigata Prefectural Fisheries and Marine Research Institute (2007, 2008, 2009, and 2010) for (c) and (d), respectively. A dotted line in each figure is a $1: 1$ line.

tropical/subtropical corals. With ocean warming, the $18^{\circ} \mathrm{C}$ isotherm during the coldest month is moving northward along the eastern coast of Japan. By the end of this century, the entire eastern coast of Japan south of Tokyo will have become suitable for the growth of tropical/subtropical corals on the basis of temperature alone (see also Yara et al., 2011).

At the same time, the $30^{\circ} \mathrm{C}$ isotherm in the hottest month of each year is moving northward as well. By the 2050s, the $30^{\circ} \mathrm{C}$ isoline is projected to enter the domain from the south (Fig. 3). By 2070s, large areas on the eastern coast of West Japan (Kyushu and Shikoku Islands; Fig. 1) will experience SSTs above this threshold, implying that these regions are expected to experience severe and repeated coral bleaching events (Yara et al., 2009). Taken together, habitats suitable for tropical/subtropical corals identified solely on the basis of the temperature tolerance are moving northward, but increasingly become smaller in area. This is because the northern limit is moving northward more slowly (by $2.6 \pm 0.6 \mathrm{~km} \mathrm{yr}^{-1}$ ) than the southern boundary is (by $7.8 \pm 0.0 \mathrm{~km} \mathrm{yr}^{-1}$ ), computed on the basis of one model.

Ocean acidification may worsen this temperature-induced habitat restriction substantially. As the isotherms are moving northward, the isolines of $\Omega_{\text {arag }}$ are moving southward, pushing current habitats around Japan below the $\Omega_{\text {arag }}=3$ thresh- old by the 2030s; i.e., we project that within a few decades, these areas may become "unsuitable" for growth for the tropical/subtropical coral communities (Fig. 3), if these communities are unable to adapt to changes in their present biogeochemical habitat. The change in the areal extent of habitats suitable for present coral communities around Japan becomes even more evident in Fig. 4. Figure 4 highlights that, by the 2030s, all of the areas around Japan that have suitable temperatures for tropical/subtropical corals are projected to be bathed in waters with $\Omega_{\text {arag }}<3$. Given the immediacy of this date, this projection is largely independent of the particular emission trajectory. Within the next $20 \mathrm{yr}$, the atmospheric $\mathrm{CO}_{2}$ concentration of even substantially smaller emission trajectories will not differ much from that of the A2 scenario (Gruber et al., 2012).

Overall, the tropical/subtropical coral communities around Japan are projected to experience conditions far outside their present range. By the 2020s, the total area suitable for tropical/subtropical coral communities, defined by $18^{\circ} \mathrm{C} \leq \mathrm{SST}<30^{\circ} \mathrm{C}$ and $\Omega_{\mathrm{arag}} \geq 3.5$ in this study, will increase by only $5 \%$ due to the elevated SST, but it will decrease by $57 \%$ due to the decrease in $\Omega_{\text {arag }}$ (Fig. 5). Unless tropical/subtropical coral communities are able to adapt to biogeochemical conditions outside the current range of 


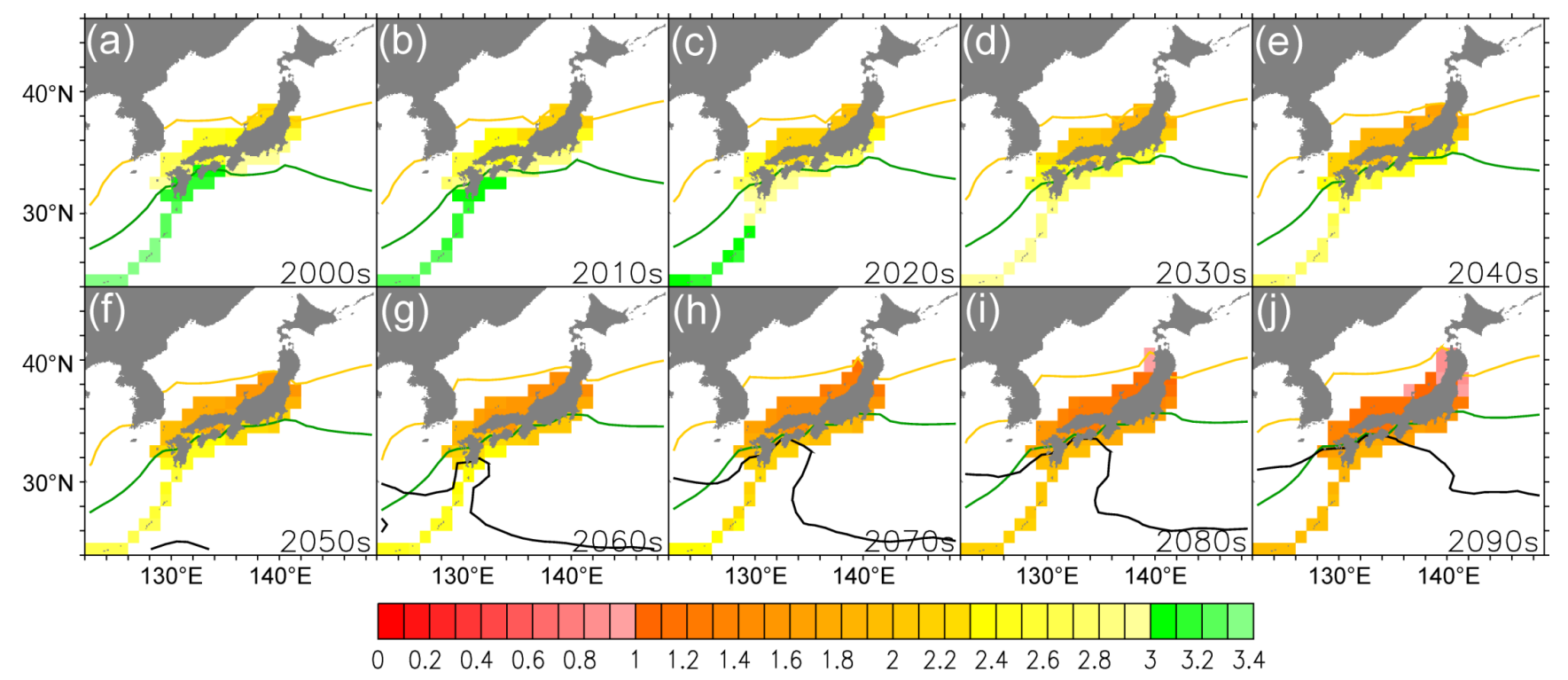

Fig. 3. Projected 10-yr average SST for the coldest months and $\Omega_{\text {arag }}$ as the annual lowest value during 2000s-2090s for the mean of four models. Lines depict the isolines of SST $=18^{\circ} \mathrm{C}$ (green lines) and SST $=10^{\circ} \mathrm{C}$ (yellow lines) during the coldest months, and the SST isoline $=30^{\circ} \mathrm{C}$ (black lines) during the hottest months. Shades denote the annual lowest $\Omega_{\text {arag values. }}$.

variability, the effects of global warming and ocean acidification will decrease the area of suitable habitats for tropi$\mathrm{cal} / \mathrm{subtropical}$ corals by $55 \%$ by the 2020 s, and in the 2030 s this area will have completely disappeared.

Figure 6 shows the projected SST and $\Omega_{\text {arag }}$ in the 21st century for Kushimoto-Shirahama $\left(33.5^{\circ} \mathrm{N}, 135.7^{\circ} \mathrm{E}\right)$ and Tateyama $\left(35.0^{\circ} \mathrm{N}, 139.8^{\circ} \mathrm{E}\right)$, where migration of the tropi$\mathrm{cal} /$ subtropical coral community has started and on-site monitoring of the poleward range expansion of coral habitats has been conducted (Yamano et al., 2011; Yara et al., 2011). Until the 2030s, both Kushimoto-Shirahama and Tateyama are projected to be located within the "suitable" regime in terms of SST, but, in terms of $\Omega_{\text {arag }}$, the sites will already have moved out of the "suitable" and into the "marginal" regime in the 2010s. Therefore, we project the negative effects of ocean acidification to precede the positive effect of global warming on tropical/subtropical coral reef formation at these two sites.

\subsubsection{Temperate coral communities}

The projected poleward expansion of habitats for temperate coral communities during the 21 st century, as indicated by the shift in the $10^{\circ} \mathrm{C}$ isotherm, implies a shift of the northern boundary of the temperate coral habitat from Sadogashima Island $\left(38.0^{\circ} \mathrm{N}, 138.2^{\circ} \mathrm{E}\right)$ to the Tsugaru Strait $\left(41.3^{\circ} \mathrm{N}\right.$, $140.4^{\circ} \mathrm{E}$, Figs. 1 and 3). Thus, the entire mainland of Japan will become a potential coral habitat in terms of SST by the end of the 21 st century. While the Honshu Island west of Tokyo, and northern Shikoku and Kyushu Islands are currently habitats for temperate corals, they are projected to host both tropical/subtropical and temperate coral communities in the future, as projected by Yara et al. (2011).

However, coral communities in these regions are projected to experience unprecedented low levels of $\Omega_{\text {arag }}$ due to ocean acidification. Figure $4 \mathrm{~b}$ shows the projected temporal changes in $\Omega_{\text {arag }}$ for the temperate coral community. For the present period (in 2010s), the models simulate that $77 \%$ of the temperate coral community habitats exist in waters with $\Omega_{\operatorname{arag}} \geq 2.3$, i.e., within the limits of suitability. However, over the course of the 21 st century, areas with $\Omega_{\text {arag }} \geq 2.3$ will decrease. In the $2080 \mathrm{~s}, 8 \%$ of the current temperate coral community is projected to experience undersaturation $\left(\Omega_{\mathrm{arag}}<1\right)$. At the end of the 21 st century, one-fifth of the current temperate coral habitat is projected to experience undersaturation, indicating that also temperate coral habitats will become endangered due to ocean acidification, despite their substantially higher tolerance for low $\Omega_{\text {arag }}$ conditions.

\subsection{Speed of coral habitat transitions}

We averaged SST and $\Omega_{\text {arag }}$ longitudinally and projected the progression of critical $\Omega_{\mathrm{arag}}$ - and SST-isolines onto the north-south (latitudinal) axis to estimate the speed of change in these variables. The poleward expansion due to changes in SST proceeded with a latitudinal speed of $2.6 \pm$ $0.6 \mathrm{~km} \mathrm{yr}^{-1}$ for the $18^{\circ} \mathrm{C}$ isoline (northern limit of the tropical/subtropical coral community) and at $1.2 \pm 0.8 \mathrm{~km} \mathrm{yr}^{-1}$ for the $10{ }^{\circ} \mathrm{C}$ isoline (northern limit of temperate coral occurrence).

These estimated speeds are similar to those of $1 \mathrm{~km} \mathrm{yr}^{-1}$ for the potential habitat expansion of tropical/subtropical 


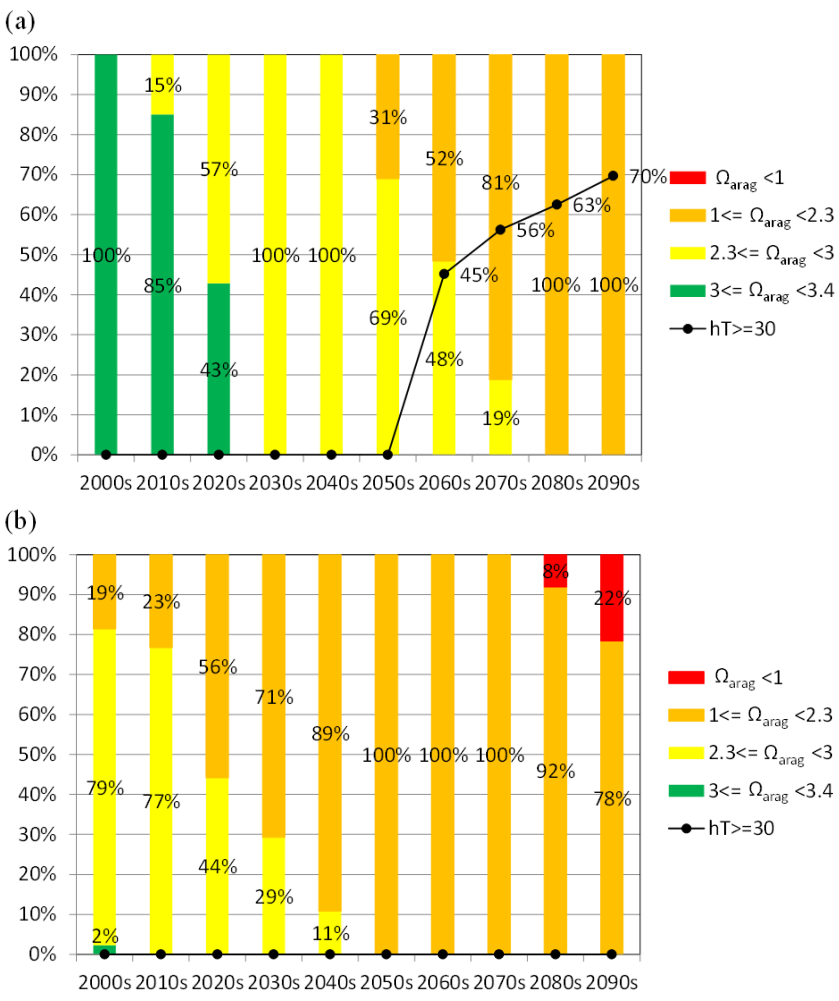

Fig. 4. Projected temporal changes in the surface area of coral habitats where the monthly-mean SST in the coldest months for 2000s-2090s is (a) $\geq 18^{\circ} \mathrm{C}$ (tropical/subtropical coral community) and (b) $10-18{ }^{\circ} \mathrm{C}$ (temperate coral community), respectively. Colors represent the domain of $\Omega_{\mathrm{arag}}<1$ (in red), $1 \leq \Omega_{\mathrm{arag}}<2.3$ (in orange), $2.3 \leq \Omega_{\text {arag }}<3$ (in yellow), and $3 \leq \Omega_{\text {arag }}<3.4$ (in green), respectively. Black lines show projected ratio of the surface area where the SST during the hottest months is $\geq 30^{\circ} \mathrm{C}$ in each domain.

coral communities and $4 \mathrm{~km} \mathrm{yr}^{-1}$ for the poleward migration of temperate coral habitats, respectively, predicted by Yara et al. (2011). However, both model results are notably smaller than the observed speed of the recent expansion of tropical coral habitats of up to $14 \mathrm{~km} \mathrm{yr}^{-1}$ (Yamano et al., 2011). The difference between the observed speed and our projected one is presumably caused by two factors (see also Yara et al., 2011): first, our speeds are based on decadal averages of the potential habitat expansion of an entire community, while Yamano et al. (2011) analyzed the speed of new colony settlement for specific indicator species. Second, we only consider here the influence of SST, while the observed migration speed might have been enhanced due to other factors, such as water depth, salinity, nutrient concentration, and competition with large seaweeds, none of which we considered in this study. Notwithstanding these differences, we conclude that if SST were the only factor, we would project species to keep up with the rate of change, and that entire coral ecosystems would migrate poleward without major impediments.

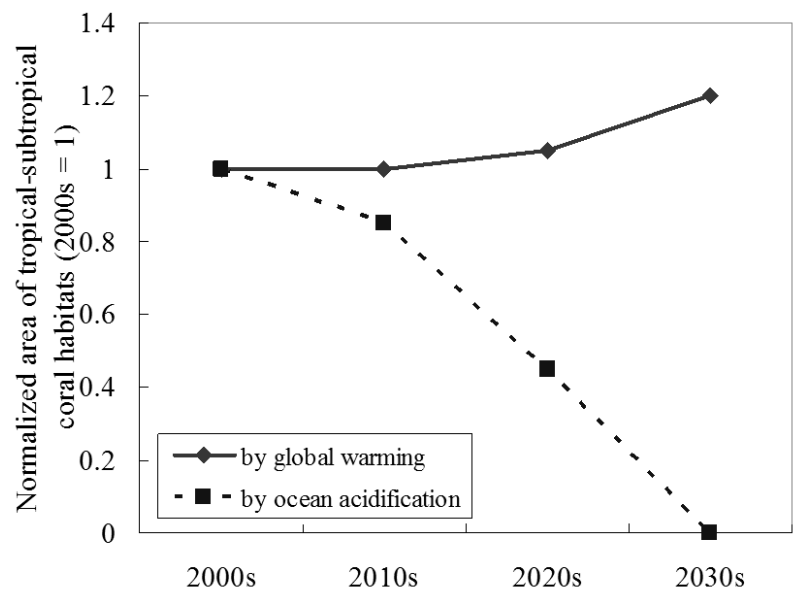

Fig. 5. Projected temporal changes in the normalized surface area of tropical/subtropical coral habitats in 2000s through 2030s (as of $2000 \mathrm{~s}=1$ ). A solid line shows the area increased by SST warming due to global warming. A dotted line denotes that decreased by $\Omega_{\text {arag decrease due to ocean acidification. }}$

However, the southward progression of the reduction in $\Omega_{\text {arag }}$ is likely to limit this expansion for those species sensitive to ocean acidification. The isolines of $\Omega_{\text {arag }}=3$ and $\Omega_{\text {arag }}=2.3$ move southwards with a latitudinal velocity of $21.1 \pm 1.7 \mathrm{~km} \mathrm{yr}^{-1}$ and $28.2 \pm 11.6 \mathrm{~km} \mathrm{yr}^{-1}$, respectively. The speed of these changes is of the order of or even faster than the migration speeds observed by Yamano et al. (2011), suggesting that migration towards areas with higher $\Omega_{\text {arag }}$ is not likely to be a successful option for the affected coral communities. The migration could be additionally slowed down by the negative impacts of ocean acidification on a range of processes involved in coral reproduction, such as fertilization, settlement and growth of early life stages of Acropora palmata (Albright et al., 2010), and sperm flagellar motility in Acroporidae (Morita et al., 2009), any of which may decrease future migration speeds. Additionally, coral migration towards the south will not be favored in parts of the east coast of Japan, due to the strong poleward Kuroshio Current.

\subsection{Limitations of this study}

There are a number of caveats that need to be considered when interpreting our results. First, our projections depend on the choice of the $\mathrm{CO}_{2}$ emission scenario, which assumes business-as-usual emissions over the 21 st century. Second, we rely on climate model results combined with simplified indices that have inherent uncertainties. And third, our definition of coral habitats considers neither acclimation nor adaptation, which would permit the corals to expand outside their current ranges and substantially reduce their susceptibility to ocean warming and ocean acidification (Pandolfi et al., 2011). These limitations impact our projections of coral habitat decline and are discussed in detail in the following subsections. 

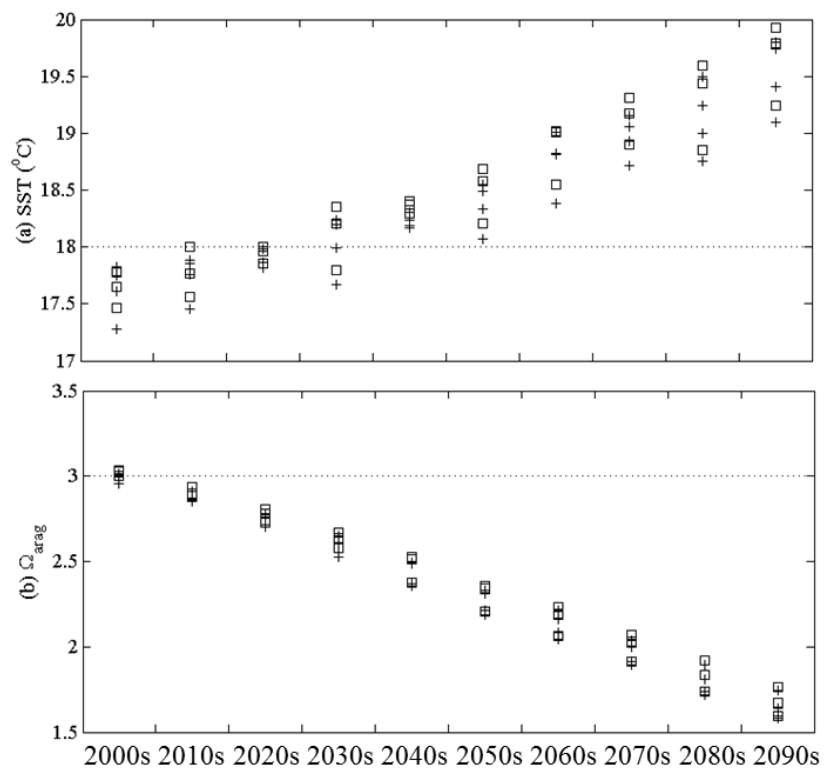

Fig. 6. Decadal-mean (a) SST $\left({ }^{\circ} \mathrm{C}\right)$ during the coldest months and (b) annual lowest $\Omega_{\text {arag }}(2000 \mathrm{~s}-2090 \mathrm{~s})$ at Kushimoto-Shirahama $\left(135.7^{\circ} \mathrm{E}, 33.5^{\circ} \mathrm{N}\right)$ and Tateyama $\left(139.8^{\circ} \mathrm{E}, 35.0^{\circ} \mathrm{N}\right)$ projected by the four climate models. Squares denote the projected SST and $\Omega_{\text {arag }}$ at Kushimoto-Shirahama. Crosses show the projected SST and $\Omega_{\text {arag }}$ at Tateyama. A dotted line in (a) and (b) denotes a $\mathrm{SST}=18^{\circ} \mathrm{C}$ and $\Omega_{\text {arag }}=3$ line, respectively.

\subsection{1 $\mathrm{CO}_{2}$ emission scenario}

Both intensity and speed of global warming and ocean acidification depend strongly on the $\mathrm{CO}_{2}$ emission scenario. The scenario used in this study is the SRES A2 scenario, which assumes "business as usual" emissions throughout the 21 st century and does not include explicit climate change mitigation actions. Mitigation scenarios lead to lower changes in atmospheric $\mathrm{CO}_{2}$, to less climate change, and less ocean acidification (Joos et al., 2011). Consequently, potential future mitigation actions would reduce the impacts of ocean acidification and warming projected in this study, especially in the second half of the century.

\subsubsection{Uncertainty in the SST and $\Omega_{\text {arag }}$ projections}

Two sources of uncertainty and biases need to be considered for our SST and $\Omega_{\text {arag }}$ projections. First, uncertainties associated with our present-day climatologies and, second, uncertainties associated with the model-based future projections.

For the latter, we use the range of the four model projections as an indicator of uncertainty. It turns out that the models simulated similar changes in 10-yr mean SST in the seas close to Japan (Fig. 7a), whereas their $\Omega_{\text {arag }}$ projections deviate more strongly from each other (Fig. 7b). Deviations in SST and $\Omega_{\text {arag }}$ are largest in the Pacific Ocean south of Tokyo $\left(35.4^{\circ} \mathrm{N}, 139.5^{\circ} \mathrm{E}\right.$; Fig. 1$)$, because the monthly-mean iso- lines of SST $=18^{\circ} \mathrm{C}$ during the coldest months and $\Omega_{\text {arag }}=3$ as the lowest annual value were predicted to be located south of the Kuroshio Current (Yara et al., 2011). In this region, the latitudinal SST and $\Omega_{\text {arag }}$ gradients are both small, so slight differences in the projected SST and $\Omega_{\mathrm{arag}}$ among the models lead to large differences in the location of the isolines. Furthermore, the coarse resolution of the models results in a poor representation of small-scale features such as enclosed regions or strong narrow currents.

The differences between the models decrease after the 2030s when the monthly-mean isolines of SST $=18^{\circ} \mathrm{C}$ during the coldest months have shifted away from the Kuroshio Current in which the latitudinal SST gradient is relatively large (Yara et al., 2011). SST anomalies are highly consistent among the models for the $18^{\circ} \mathrm{C}$ and $10^{\circ} \mathrm{C}$ isolines. However, the models did not simulate the occurrence of high SSTs in the southern part of our domain consistently. The $30^{\circ} \mathrm{C}$ isothermal line, one of the thresholds for an increased risk of coral bleaching (Kayanne et al., 1999), was predicted to reach our domain from the south in the 2030s by one model, but only in the 2060s by another model (Fig. 7a). Hence, the uncertainty in the simulation of the upper SST threshold by different models is larger than that for the lower SST threshold. Similarly, the uncertainty in the simulation of $\Omega_{\text {arag }}$ by different models increases with time. The location of the northern limit of the tropical/subtropical coral community and temperate coral occurrence (defined by the isoline of $\Omega_{\text {arag }}=3$ and 2.3 , respectively) is projected differently between models for the period after 2010s and after 2040s, respectively (Fig. 7b).

The uncertainties associated with the climatologies (see Sect. 3.1) also directly affect our estimates. While the comparisons with the in situ data revealed relatively small biases for SST, the biases for $\Omega_{\text {arag }}$ are considerable and negative (Fig. 2). This means that our projected transitions to low $\Omega_{\text {arag }}$ occur likely too early and that the suitable areas are in reality likely larger than projected. The impact of this bias on our estimates is difficult to evaluate given the very limited data available for the evaluation of our climatologies, but we consider it to be less than one decade. We consider this uncertainty by expanding the decades when certain transitions occur to at least two decades (Fig. 5).

\subsubsection{Biological responses to ocean warming and acidification}

So far, we have not considered the potential for acclimation and adaptation to ocean warming and acidification because of the very large uncertainties associated with the quantification of these processes. However, several recent studies pointed out that such biological responses have the potential to alleviate much of the impact of warming and ocean acidification on corals (Pandolfi et al., 2011). 


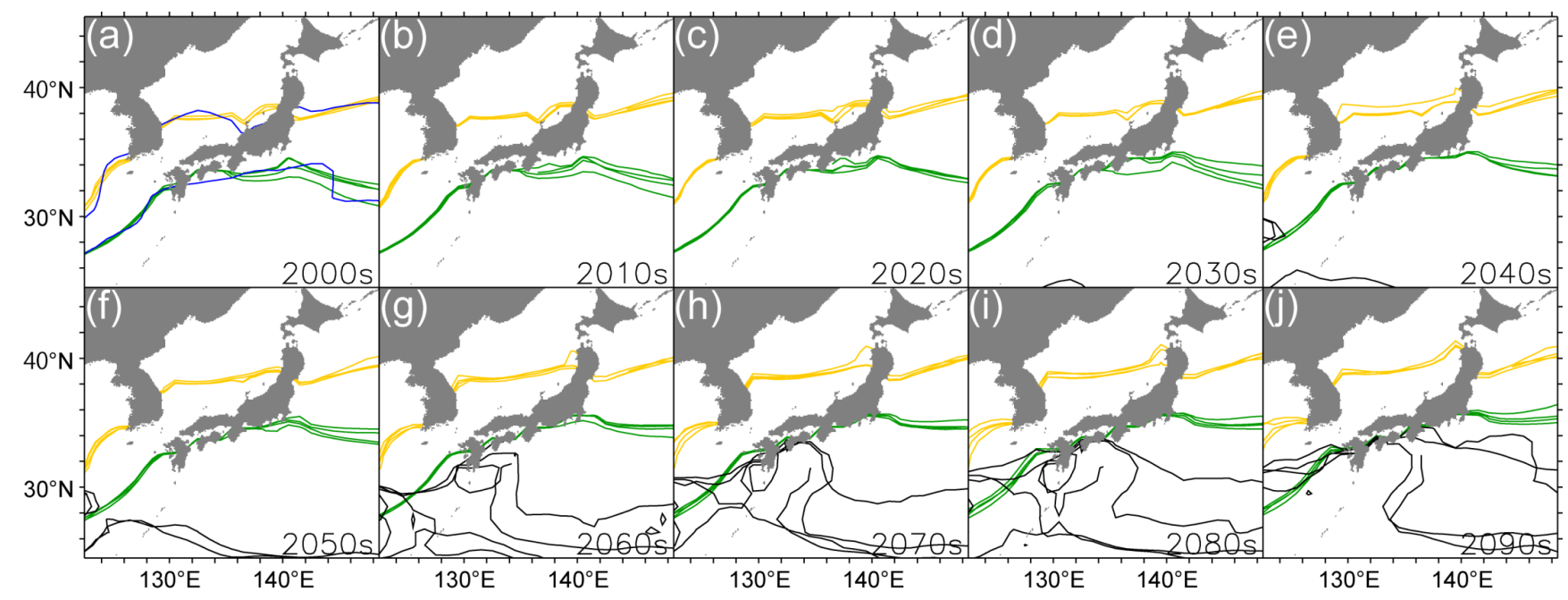

Fig. 7a. Projected 10-yr mean northern limit of the tropical/subtropical coral community (defined by the isothermal lines of SST $=18^{\circ} \mathrm{C}$; green lines) and temperate coral occurrence (defined by the isothermal lines of SST $=10^{\circ} \mathrm{C}$; yellow lines) defined by SST during the coldest months of each decade in seas close to Japan in 2000s-2090s, obtained by the four climate models. The blue lines in (a) denote the 10-yr mean observed monthly-mean isothermal lines of SST $=18^{\circ} \mathrm{C}$ and $10^{\circ} \mathrm{C}$ during the coldest months, estimated by NOAA OISST. The black lines denote isothermal lines of SST $=30^{\circ} \mathrm{C}$ during the hottest months.

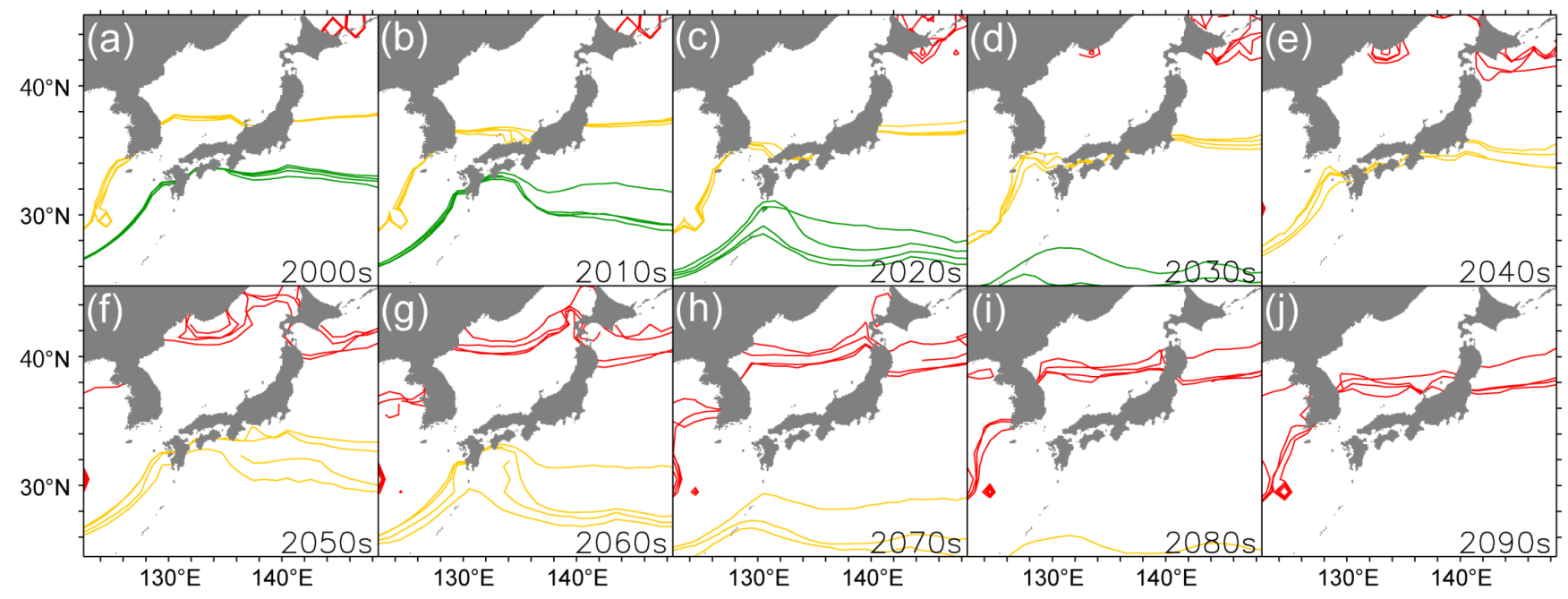

Fig. 7b. Same as in Fig. 7a, but for projected 10-yr mean northern limit of tropical/subtropical coral communities (defined by the isolines of $\Omega_{\text {arag }}=3$; green lines) and temperate coral occurrence (defined by the isolines of $\Omega_{\text {arag }}=2.3$; yellow lines), defined by $\Omega_{\text {arag }}$ as the lowest value in each decade. Red lines denote the isolines of $\Omega_{\text {arag }}=1$ as a criterion for the aragonite undersaturation level.

For example, Cooper et al. (2012) pointed out that ocean warming may not only permit coral communities to migrate poleward, but also may have a strong positive effect on coral calcification, possibly permitting them to overcome the negative effect of ocean acidification. Corals may be able to counter the effect of ocean acidification by upregulating their pH (McCulloch et al., 2012a, b). Such mechanisms must be active in corals that are capable of thriving healthfully in waters with $\Omega_{\text {arag }}<3$, implying high interspecific variability in calcification rates or adaptation to low $\Omega_{\text {arag }}$ (e.g., Manzello, 2010; Cohen and Holcomb, 2009). In fact some studies reported survival of some coral species upon skeleton disso- lution (e.g., Fine and Tchernov, 2007), thus confirming the naked coral hypothesis (Stanley Jr. and Fautin, 2001). Corals may also have a lower susceptibility to thermal stress than previously thought thanks to a number of adaptive responses (Guest et al., 2012; Howells et al., 2012). Finally Pandolfi et al. (2011) emphasized the genetic diversity and the species to species variability in the responses of corals to ocean warming and ocean acidification. This creates, especially when considering also the spatiotemporal evolution of the stressors, a complex mosaic of ecosystem response that our simple SST and $\Omega_{\text {arag }}$-based approach is not able to capture. 
Despite these new insights, our overall understanding of the response of coral communities to environmental stressors, and especially when they co-occur (Manzello, 2010), is very poor. It is likely that such mechanisms will alleviate the severity of some of our projections. At the same time, our analysis also assumes that the newly emerging habitats will become occupied, requiring a substantial migration speed and a high rate of success in settlement. Furthermore, Frieler et al. (2012) recently pointed out that the development of thermal stress, despite optimistic assumptions about the speed at which corals can adapt to it, will occur so quickly in this century that coral communities will become severely damaged.

\section{Conclusions}

Under unabated anthropogenic $\mathrm{CO}_{2}$ emissions that are strongly dependent on current and future political and economic decisions, future coral habitats in seas surrounding Japan will be sandwiched between high temperature regions, where the frequency of coral bleaching is predicted to increase, and low aragonite saturation states that will reduce calcification rates and overall reproductive success.

The impact of these physical and chemical changes in habitats on the actual coral communities depends critically on their ability to adapt and their ability to occupy newly emerging habitats. While we assumed no ability for adaptation in our base case, the recently emerging studies point out the large diversity of such adaptive capabilities. While it is highly uncertain whether corals in the seas close to Japan will be able to adapt and overcome (in part) their severe habitat restriction, it is certain that ocean warming and ocean acidification will alter reef biodiversity and ecosystems.

Future studies must include the effects of other factors on corals besides SST increase and $\Omega_{\text {arag }}$ decrease, such as changes in water depth, salinity, nutrient concentration, and competition with large seaweeds, and should focus not only on the tropical/subtropical coral community but also consider the temperate coral community. In particular, observational studies are necessary to determine the vulnerability of temperate coral species to low $\Omega_{\text {arag }}$ values.

Acknowledgements. We thank D. Loher for providing the interpolated GLODAP/observational fields and L. Bopp, J. Segschneider, and V. Cocco for providing the IPSL, MPIM, and CCSM3 model results. Comments from John Pandolfi and an anonymous reviewer significantly improved the paper. M. V. and N. G. acknowledge funding by ETH Zurich. C. H. was funded by the EU FP7 Integration project EPOCA (European Project on Ocean Acidification) under grant agreement no. 211384. M. S. acknowledges support from the Swiss National Science Foundation as well as from the "European Project on Ocean Acidification" EPOCA (211384) and the European Project CARBOCHANGE (264879) which both received funding from the European Commission's Seventh Framework Programme (FP7/20072013). Y. Yara and H. Y. were supported by the Strategic Research and Development Project (S-5 and S-9) of the Ministry of the Environment, Japan. Y. Yara was also supported by the JSPS Institutional Program for Young Researcher Overseas Visits. The NCAR CSM1.4-carbon and CCSM3 simulations were carried out at the Swiss National Supercomputing Centre (CSCS) in Manno, Switzerland.

Edited by: W. Kiessling

\section{References}

Albright, R., Mason, B., Miller, M., and Langdon, C.: Ocean acidification compromises recruitment success of the threatened Caribbean coral Acropora palmata, P. Natl. Acad. Sci. USA, 107, 20400-20404, 2010.

Anthony, K. R. N., Kline, D. I., Diaz-Pulido, G., Dove, S., HoeghGuldberg, O.: Ocean acidification causes bleaching and productivity loss in coral reef builders, P. Natl. Acad. Sci. USA, 105, 17442-17446, 2008.

Anthony, K. R. N., Maynard, J. A., Diaz-Pulido, G., Mumby, P. J., Marshall, P. A., Cao, L., and Hoegh-Guldberg, O.: Ocean acidification and warming will lower coral reef resilience, Glob. Change Biol., 17, 1798-1808, 2011.

Buddemeier, R. W., Kleypas, J. A., and Aronson, R. B.: Coral Reefs \& Global Climate Change: Potential Contributions of Climate Change to Stresses on Coral Reef Ecosystems, Report prepared for the Pew Center on Global Climate Change, Arlington, VA, USA, 56 pp., 2004.

Cohen, A. L. and Holcomb, M.: Why Corals Care About Ocean Acidification: Uncovering the Mechanism, Oceanography, 22, 118-127, 2009.

Cooper, T. F., O'Leary, R. A., and Lough, J. M.: Growth of Western Australian Corals in the Anthropocene, Science, 335, 593-596, doi:10.1126/science.1214570, 2012.

Doney, S., Lindsay, K., Fung, I., and John, J.: Natural variability in a stable, 1000-yr global coupled climate-carbon cycle simulation, J. Climate, 19, 3033-3054, 2006.

Feely, R. A., Sabine, C. L., Lee, K., Berelson, W., Kleypas, J., Fabry, V. J., and Millero, F. J.: Impact of Anthropogenic $\mathrm{CO}_{2}$ on the $\mathrm{CaCO}_{3}$ System in the Oceans, Science, 305, 362-366, doi:10.1126/science.1097329, 2004.

Feely, R. A., Doney, S. C., and Cooley, S. R.: Ocean acidification: present conditions and future changes in a high- $\mathrm{CO}_{2}$ world, Oceanography, 22, 36-47, 2009.

Fine, M. and Tchernov, D.: Scleractinian coral species survive and recover from decalcification, Science, 315, 1811, doi:10.1126/science.1137094, 2007.

Friedlingstein, P., Cox, P., Betts, R., Bopp, L., Von Bloh, W., Brovkin, V., Cadule, P., Doney, S., Eby, M., Fung, I., Bala, G., John, J., Jones, C., Joos, F., Kato, T., Kawamiya, M., Knorr, W., Lindsay, K., Matthews, H. D., Raddatz, T., Rayner, P., Reick, C., Roeckner, E., Schnitzler, K. G., Schnur, R., Strassmann, K., Weaver, A. J., Yoshikawa, C., and Zeng, N.: Climate-Carbon Cycle Feedback Analysis: Results from the C4MIP Model Intercomparison: Evolution of carbon sinks in a changing climate, J. Climate, 19, 3337-3353, 2006.

Frieler, K., Meinshausen, M., Golly, A., Mengel, M., Lebek, K., Donner, S. D., and Hoegh-Guldberg, O.: Limiting global warm- 
ing to $2{ }^{\circ} \mathrm{C}$ is unlikely to save most coral reefs, Nature Climate Change, online first: doi:10.1038/NCLIMATE1674, 2012.

Fung, I., Doney, S., Lindsay, K., and John, J.: Evolution of carbon sinks in a changing climate, P. Natl. Acad. Sci. USA, 102, 11201-11206, 2005.

Gattuso J.-P., Frankignoulle M., Bourge I., Romaine S., and Buddemeier, R. W.: Effect of calcium carbonate saturation of seawater on coral calcification, Global Planet. Change, 18, 37-46, 1998.

Greenstein, B. and Pandolfi, J.: Escaping the heat: range shifts of reef coral taxa in coastal Western Australia, Global Change Biol., 14, 513-528, doi:10.1111/j.1365-2486.2007.01506.x, 2008.

Gruber, N., Hauri, C., Lachkar, Z., Loher, D., Frölicher, T. L., and Plattner, G.-K.: Rapid progression of ocean acidification in the California Current System, Science, 337, 220-223, doi:10.1126/science.1216773, 2012.

Guest, J. R., Baird, A. H., Maynard, J. A., Muttaqin, E., Edwards, A. J., Campbell, S. J., Yewdall, K., Affendi, Y. A., and Chou, L. M.: Contrasting Patterns of Coral Bleaching Susceptibility in 2010 Suggest an Adaptive Response to Thermal Stress, PLoS ONE, 7, e33353, doi:10.1371/journal.pone.0033353, 2012.

Guinotte, J. M., Buddemeier, R. W., and Kleypas, J. A.: Future coral reef habitat marginality: temporal and spatial effects of climate change in the Pacific basin, Coral Reefs, 22, 551-558, 2003.

Hoegh-Guldberg, O: Low coral cover in a high- $\mathrm{CO}_{2}$ world, J. Geophys. Res., 110, C09S06, doi:10.1029/2004JC002528, 2005.

Hoegh-Guldberg, O., Mumby, P. J., Hooten, A. J., Steneck, R. S., Greenfield, P., Gomez, E., Harvell, C. D., Sale, P. F., Edwards, A. J., Caldeira, K., Knowlton, N., Eakin, C. M., Iglesias-Prieto, R., Muthiga, N., Bradbury, R. H., Dubi, A., and Hatziolos, M. E.: Coral reefs under rapid climate change and ocean acidification, Science, 318, 1737-1742, 2007.

Honma, Y. and Kitami, T.: Fauna and flora in the waters adjacent to the Sado Marine Biological Station, Ann. Rep. Sado Mar. Biol. Sta., Niigata University, 8, 7-81, 1978.

Hori, N.: Coral reefs in Japan, Kagaku, 50, 111-122, 1980 (in Japanese).

Howells, E. J., Beltran, V. H., Larsen, N. W., Bay, L. K., Willis, B. L., and van Oppen, M. J. H.: Coral thermal tolerance shaped by local adaptation of photosymbionts, Nature Climate Change, 2, 116-120, doi:10.1038/NCLIMATE1330, 2012.

Ikeda, E., Iryu, Y., Sugihara, K., Ohba, H., and Yamada, T.: Bathymetry, biota, and sediments on the Hirota reef, Tane-gashima; the northernmost coral reef in the Ryukyu Islands, Isl. Arc., 15, 407-419, 2006.

IPCC: Summary for Policymakers, Emissions Scenarios, A Special Report of IPCC Working Group III, Intergovernmental Panel on Climate Change, ISBN 92-9169-113-5, 2000.

IPCC: Climate Change 2007: The Physical Science Basis. Contribution of Working Group I to the Fourth Assessment Report of the Intergovernmental Panel on Climate Change, edited by: Solomon, S., Qin, D., Manning, M., Chen, Z., Marquis, M., Averyt, K. B., Tignor, M., and Miller, H. L., Cambridge University Press, Cambridge, UK and New York, NY, USA, 996 pp., 2007.

Ishii, M., Kosugi, N., Sasano, D., Saito, S., Midorikawa, T., and Inoue, H. Y.: Ocean acidification off the south coast of Japan: A result from time series observations of $\mathrm{CO}_{2}$ parameters from 1994 to 2008, J. Geophys. Res.-Ocean., 116, C06022, doi:10.1029/2010JC006831, 2011.
Joos, F., Frölicher, T. L., Steinacher, M., and Plattner, G.-K.: Impact of climate change mitigation on ocean acidification projections, in: Ocean Acidification, Chap. 14, edited by: Gattuso, J.-P. and Hansson, L., Oxford University Press, New York, USA, 272 290, 2011.

Kan, H., Nakashima, Y., Ohashi, T., Hamanaka, N., Okamoto, T., Nakai, T., and Hori, N.: Drilling Research of a high-latitude coral reef in Mage Island, Satsunan Islands, Japan, Okayama University Earth Science Reports, 12, 49-58, 2005.

Kayanne, H., Harii, S., Yamano, H., Tamura, M., Ide, Y., and Akimoto F.: Changes in living coral coverage before and after the 1998 bleaching event on coral reef flats of Ishigaki Island, Ryukyu Islands, Galaxea, J. Cataract. Refr. Surg., 1, 73-82, 1999 (in Japanese with English abstract).

Kleypas, J. A., McManus, J. W., and Meñez, L. A. B.: Environmental limits to coral reef development: where do we draw the line?, Am. Zool., 39, 146-159, 1999a.

Kleypas, J. A., Buddemeier, R. W., Archer, D., Gattuso, J.-P., Langdon, C., and Opdyke, B. N.:, Geochemical consequences of increased atmospheric carbon dioxide on coral reefs, Science, 284, 118-120, 1999b.

Kleypas, J. A., Feely, R. A., Fabry, V. J., Langdon, C., Sabine, C. L., and Robbins, L. L.: Impacts of ocean acidification on coral reefs and other marine calcifiers: A guide for future research, report of a workshop held 18-20 April 2005, St. Petersburg, FL, sponsored by NSF, NOAA, and the US Geological Survey, 88 pp., 2006.

Langdon, C., Takahashi, T., Sweeney, C., Chipman, D., Goddard, J., Marubini, F., Aceves, H., Barnett, H., and Atkinson, M. J.: Effect of calcium carbonate saturation state on the calcification rate of an experimental coral reef, Global Biogeochem. Cy., 14, 639-654, doi:10.1029/1999GB001195, 2000.

Langdon, C., Broecker, W. S., Hammond, D. E., Glenn, E., Fitzsimmons, K., Nelson, S. G., Peng, T.-H., Hajdas, I., and Bonani, G.: Effect of elevated $\mathrm{CO}_{2}$ on the community metabolism of an experimental coral reef, Global Biogeochem. Cy., 17, 1011, doi:10.1029/2002GB001941, 2003.

Lee, K., Tong, L. T., Millero, F. J., Sabine, C. L., Dickson, A. G., Goyet, C., Park, G.-H., Wanninkhof, R., Feely, R. A., and Key, R. M.: Global relationships of total alkalinity with salinity and temperature in surface waters of the world's oceans, Geophys. Res. Lett., 33, L19605, doi:10.1029/2006GL027207, 2006.

Maier-Reimer, E., Kriest, I., Segschneider, J., and Wetzel, P.: The HAMburg Ocean Carbon Cycle model HAMOCC5.1, Berichte zur Erdsystemforschung 14/2005, Max Planck-Institut für Meteorologie, Hamburg, Germany, 2005.

Manzello, D. P.: Coral growth with thermal stress and ocean acidification: lessons from the eastern tropical Pacific, Coral Reefs, 29, 749-758, doi:10.1007/s00338-010-0623-4, 2010.

Marsland, S. J., Haak, H., Jungclaus, J. H., Latif, M., and Roske, F.: The Max-Planck-Institute global ocean/sea ice model with orthogonal curvilinear coordinates, Ocean Model., 5, 91-127, 2003.

McCulloch, M., Falter, J., Trotter, J., and Montagna, P.: Coral resilience to ocean acidification and global warming through pH up-regulation, Nature Climate Change, 2, 623-627, doi:10.1038/NCLIMATE1473, 2012a.

McCulloch, M., Trotter, J., Montagna, P., Falter, J., Dunbar, R., Freiwald, A., Försterra, G., López Correa, M., Maier, C., Rüggeberg, A., and Taviani, M.: Resilience of cold-water scleractinian corals 
to ocean acidification: Boron isotopic systematics of $\mathrm{pH}$ and saturation state up-regulation, Geochim. Cosmochim. Ac., 87, 21$34,2012 b$.

Meissner, K. J., Lippmann, T., and Sen Gupta, A.: Large-scale stress factors affecting coral reefs: open ocean sea surface temperature and surface seawater aragonite saturation over the next 400 years, Coral Reefs, 31, 303-319, doi:10.1007/s00338-011-08668, 2012.

Meehl, G. A., Stocker, T. F., Collins, W. D., Friedlingstein, P., Gaye, A. T., Gregory, J. M., Kitoh, A., Knutti, R., Murphy, J. M., Noda, A., Raper, S. C. B.,Watterson, I. G.,Weaver, A. J., and Zhao, Z.C.: Climate Change 2007: The Physical Science Basis. Contribution of Working Group I to the Fourth Assessment Report of the Intergovernmental Panel on Climate Change, chap. Global Climate Projections, Cambridge University Press, Cambridge, UK and New York, NY, USA, 747-846, 2007.

Midorikawa, T., Ishii, M., Saito, S., Sasano, D., Kosugi, N., Motoi, T., Kamiya, H., Nakadate, A., Nemoto, K., and Inoue, H. Y.: Decreasing $\mathrm{pH}$ trend estimated from 25 -yr time series of carbonate parameters in the western North Pacific, Tellus, 62B, 649-659, 2010.

Moore, J. K., Doney, S. C., and Lindsay, K.: Upper ocean ecosystem dynamics and iron cycling in a global threedimensional model, Global Biogeochem. Cy., 18, GB4028, doi:10.1029/2004GB002220, 2004.

Morita, M., Suwa, R., Iguchi, A., Nakamura, M., Shimada, K., Sakai, K., and Suzuki, A.: Ocean acidification reduces sperm flagellar motility in broadcast spawning reef invertebrate, $\mathrm{Zy}$ gote, 18, 103-107, 2009.

Nakai, T.: Marginal features of coral reefs in Japan, in: Tropics in Japan: Natural history of coral island, edited by: The Research Group on Coral Reef Regions in Japan, Japan, Kokon-Shoin, Tokyo, 57-65, 1990 (in Japanese).

Niigata Prefectural Fisheries and Marine Research Institute, Niigataken Suisan Kaiyo Kenkyujo Nenpo (Annual Report of Niigata Prefectural Fisheries and Marine Research Institute), 121124, 2007 (in Japanese).

Niigata Prefectural Fisheries and Marine Research Institute: Niigataken Suisan Kaiyo Kenkyujo Nenpo (Annual Report of Niigata Prefectural Fisheries and Marine Research Institute), 133136, 2008 (in Japanese).

Niigata Prefectural Fisheries and Marine Research Institute: Niigataken Suisan Kaiyo Kenkyujo Nenpo (Annual Report of Niigata Prefectural Fisheries and Marine Research Institute), 127 130, 2009 (in Japanese).

Niigata Prefectural Fisheries and Marine Research Institute: Niigataken Suisan Kaiyo Kenkyujo Nenpo (Annual Report of Niigata Prefectural Fisheries and Marine Research Institute), 121125, 2010 (in Japanese).

Orr, J. C., Fabry, V. J., Aumont, O., Bopp, L., Doney, S. C., Feely, R. A., Gnanadesikan, A., Gruber, N., Ishida, A., Joss, F., Key, R. M., Lindsay, K., Maier-Reimer, E., Matear, R., Monfray, P., Mouchet, A., Najjar, R. G., Plattner, G. K., Rodgers, K. B., Sabine, C. L., Sarmiento, J. L., Schlitzer, R., Slater, R. D., Totterdell, I. J., Weirig, M. F., Yamanaka, Y., and Yool, A.: Anthropogenic ocean acidification over the twenty first century and its impact on calcifying organisms, Nature, 437, 681-686, 2005.

Pandolfi, J. M., Connolly, S. R., Marshall, D. J., and Cohen, A. L.: Projecting Coral Reef Futures Under Global
Warming and Ocean Acidification, Science, 333, 418-422, doi:10.1126/science.1204794, 2011.

Precht, W. F. and Aronson, R. B.: Climate flickers and range shifts of reef corals, Front. Ecol. Environ., 2, 307-314, 2004.

Rodgers, K. B., Aumont, O., Menkes, C., and Gorgues, T.: Decadal variations in equatorial Pacific ecosystems and ferrocline/pycnocline decoupling, Global Biogeochem. Cy., 22, GB2019, doi:10.1029/2006GB002919, 2008.

Roeckner, E., Brokopf, R., Esch, M., Giorgetta, M., Hagemann, S., Kornblueh, L., Manzini, E., Schlese, U., and Schulzweida, U.: Sensitivity of simulated climate to horizontal and vertical resolution in the ECHAM5 atmosphere model, J. Climate, 19, 37713791, 2006.

Solomon, S., Qin, D., Manning, M., Alley, R. B., Berntsen, T., Bindoff, N. L., Chen, Z., Chidthaisong, A., Gregory, J. M., Hegerl, G. C., Heimann, M., Hewitson, B., Hoskins, B. J., Joos, F., Jouzel, J., Kattsov, V., Lohmann, U., Matsuno, T., Molina, M., Nicholls, N., Overpeck, J., Raga, G., Ramaswamy, V., Ren, J., Rusticucci, M., Somerville, R., Stocker, T. F., Whetton, P., Wood, R. A., and Wratt, D.: Climate Change 2007: The Physical Science Basis, contribution ofWorking Group I to the Fourth Assessment Report of the Intergovernmental Panel on Climate Change, chap. Technical Summary, Cambridge University Press, Cambridge, United Kingdom and New York, NY, USA, 2007.

Stanley Jr., G. D. and Fautin, D. G.: The Origin of Modern Corals, Science, 291, 1913-1914, 2001.

Steinacher, M., Joos, F., Frölicher, T. L., Plattner, G.-K., and Doney, S. C.: Imminent ocean acidification in the Arctic projected with the NCAR global coupled carbon cycle-climate model, Biogeosciences, 6, 515-533, doi:10.5194/bg-6-515-2009, 2009.

Steinacher, M., Joos, F., Frölicher, T. L., Bopp, L., Cadule, P., Cocco, V., Doney, S. C., Gehlen, M., Lindsay, K., Moore, J. K., Schneider, B., and Segschneider, J.: Projected 21st century decrease in marine productivity: a multi-model analysis, Biogeosciences, 7, 979-1005, doi:10.5194/bg-7-979-2010, 2010.

Takahashi, T., Sutherland, S. C., Wanninkhof, R., Sweeney, C., Feely, R. A., Chipman, D. W., Hales, B., Friederich, G., Chavez, F., Watson, A., Bakker, D. C. E., Schuster, U., Metzl, N., Yoshikawa-Inoue, H., Ishii, M., Midorikawa, T., Nojiri, Y., Sabine, C., Olafsson, J., Arnarson, Th. S., Tilbrook, B., Johannessen, T., Olsen, A., Bellerby, R., Körtzinger, A., Steinhoff, T., Hoppema, M., de Baar, H. J. W., Wong, C. S., Delille, B., and Bates, N. R.: Climatological mean and decadal changes in surface ocean $p \mathrm{CO}_{2}$, and net sea-air $\mathrm{CO}_{2}$ flux over the global oceans, Deep-Sea Res.-Pt. II, 56, 554-577, 2009.

Trenberth, K. E., Jones, P. D., Ambenje, P., Bojariu, R., Easterling, D., Klein Tank, A., Parker, D., Rahimzadeh, F., Renwick, J. A., Rusticucci, M., Soden, B., and Zhai, P.: Observations: Surface and Atmospheric Climate Change. In: Climate Change 2007: The Physical Science Basis. Contribution of Working Group I to the Fourth Assessment Report of the Intergovernmental Panel on Climate Change, edited by: Solomon, S., Qin, D., Manning, M., Chen, Z., Marquis, M., Averyt, K. B., Tignor M., and Miller, H. L., Cambridge University Press, Cambridge, United Kingdom and New York, NY, USA, 2007.

Veron, J. E. N.: Corals in Space and Time, The Biogeography and Evolution of the Scleractinia. Cornell Univ. Press, Ithaca, 321 pp., 1995. 
Yamano, H., Sugihara, K., and Nomura, K.: Rapid poleward range expansion of tropical reef corals in response to rising sea surface temperatures, Geophys. Res. Lett., 38, L04601, doi:10.1029/2010GL046474, 2011.

Yamano, H., Sugihara, K., Watanabe, T., Shimamura, M., and Hyeong, K.: Coral reefs at $34^{\circ} \mathrm{N}$, Japan: Exploring the end of environmental gradients, Geology, 40, 835-838, 2012.
Yara, Y., Fujii, M., Yamanaka, Y., Okada, N., Yamano, H., and Oshima, K.: Projected effects of global warming on coral reefs in seas close to Japan, J. Japan Coral Reef Soc., 11, 131-140, 2009 (in Japanese with English abstract).

Yara, Y., Oshima, K., Fujii, M., Yamano, H., Yamanaka, Y., and Okada, N.: Projection and uncertainty of the poleward range expansion of coral habitats in response to sea surface temperature warming: A multiple climate model study, Galaxea, Journal of Coral Reef Studies, 13, 11-20, 2011. 